DOI https://doi.org/10.30525/978-9934-26-040-7-56

\title{
GUARANTEES IN CRIMINAL PROCEEDING IN THE CONTEXT OF UKRAINIAN LEGISLATION AND THE CASE-LAW OF THE EUROPEAN COURT OF HUMAN RIGHTS
}

\author{
Lyoshenko O. Yu. \\ Attorney, \\ Candidate to the Ph. D. Degree at the Criminal Procedural Law, \\ Investigation and Operational Search Activities' Department \\ National University "Odesa Law Academy» \\ Odesa, Ukraine
}

In a democratic society the right to a fair trial is the most guaranteed. International legal standards of a fair trial are enshrined in Article 6 of the Convention for the Protection of Human Rights and Fundamental Freedoms (hereinafter - the Convention). The minimum procedural guarantees of that include the presumption of innocence, adversarial proceeding, equality of the parties to the proceedings, the right to legal assistance, the access to justice and the reasonableness of the length of proceedings.

Understanding the nature and mechanism of the above guarantees for a fair trial is reflected in the case-law of the European Court of Human Rights.

The Criminal Procedural Code of Ukraine (the CPC) indicates that the tasks of criminal proceeding is protection of an individual, society and the state from criminal offenses, protection of the rights, freedoms and legal interests of the parties to criminal proceedings, as well as providing with prompt, complete and unbiased investigation and trial...(Article $2 \xi 1$ of the $C P C$ of Ukraine). During criminal proceedings every procedural activity or procedural decision shall be applied within the reasonable time. The time to be considered reasonable whereas it is objectively required for exercising procedural activities and delivering the procedural decisions (Article 28 of the CPC of Ukraine). Conduction of the pre-trial proceedings within the reasonable time shall be provided by the prosecutor or investigating judge, and the trial proceedings - by the court.

According to the European Court's case-law the purpose of the reasonable time guarantee, which is applied to the criminal and non-criminal cases, is to protect all parties to the court proceedings against the excessive procedural delays. As the European Court stated in its case-law, the guarantee underlines the importance of rendering justice without delays 
which might jeopardize its effectiveness and credibility. In criminal cases, it is also designed to avoid that a person charged should remain too long in a state of uncertainty about his fate [1].

In criminal cases, the reasonable time guarantee runs from the moment that an individual is subject to a charge.

The reasonableness of the length of proceedings shall be determined in the light of the circumstances of the case and taking into account the following criteria, particular complexity of the case, the conduct of the applicant and the conduct of the authorities, occurring with the case. No particular factor is conclusive, the approach must be to examine them separately and then to assess their cumulative effect. Although, particular instances of delay attributable to the State may not seem unreasonable, they may be such when taken together. No margin of appreciation doctrine is applied, at last expressly, when determining the reasonableness of the time taken. The European Court simply makes its own assessment of the length of time taken. When it does so, it must bear in mind that Article 6 of the Convention can only require such expedition as is consistent with the proper administration of justice [2].

While defining the level of case complexity, the nature of facts, which should be stated, number of witnesses, and possibility of the cases' unification as well as the entry of new participants into the process, are taken into consideration. The excessive complexity of the case may serve as justification for extended criminal proceedings, but is not an absolute factor, which could define the absence of violating the reasonable time guarantee.

The only duty that European Court imposes is to «demonstrate the readiness to participate in all stages of the proceeding, which are directly related to it, refrain from using measures delaying the process and maximize the use of every means of domestic legislation to enhance the proceeding». In the case «Merit v. Ukraine» the European Court stated, that the plaintiff may be considered responsible for some insignificant delays in the proceeding when he was inspecting the materials of the case. Besides, in the decision of «Smirnova v. Russia» the European Court expressed the idea, that the period when the accused was hiding from investigation and trial must be eliminated from the general period of the proceeding (also decision in the case "Girolami v. Italy»).

To the criteria of criminal proceeding delays, which cause violations of reasonable time requirement, belong the following: unjustified delay in the investigation of the case, failure to conduct proceedings and approving the procedural decisions, repeated return of the criminal case for further investigation, delay and termination of the case's consideration; breaks in the hearing due to the delay in provision or collecting evidence, provided by 
the state. Sometimes it is connected primarily with the extremely excessive workload of the courts, underfunding of the courts, absence of enough number of judges and support workers.

The importance of case consideration's guarantee during the reasonable time caused the European Court to formulate the requirement regarding the necessity of availability in the national legislation of procedures and means with the help of which the suspect or accused could appeal against the length of the proceedings and speed them up.

Criminal proceeding regarding the person, kept in detention, and juvenile should be carried out immediately and considered primarily in the court.

Everyone has the right for the accusation against him to become the subject of litigation within the shortest term or the criminal proceeding to be closed. The word combination «within the shortest term» corresponds to the expression «as soon as possible», and in our opinion, introduces higher standards than provided by the Convention's right for a trial within the reasonable time [3].

The factors considered so far are ones that the European Court takes into account when considering whether the proceedings on the facts of a particular case have been conducted with a sufficient expedition. There is, however, another dimension to the reasonable time guarantee. The Convention places a duty on the Contracting parties (the States) to organize their legal systems so as to allow the courts to comply with the requirements of Article $6 \S 1$. It follows that a State may be held liable not only for any delay in the handling of a particular case in the operation of a generally expeditious system for the administration of justice, but also for a failure to increase resources in response to a backlog of cases and for structural deficiencies in its system of justice that cause delays.

Thereby, on the one hand, the decisions of the European Court sequentially form a certain standard of criminal proceedings and, on the other hand, they develop legal guidelines for judges in controversial issues of justice in the sphere of human rights as to different directions of legal influence on national legislation. Due to this, the court decisions have transformed into an important factor of legal system development, and because of their impact the new legal norms are being formed, that correspond to the international legal standards on the human rights consideration, which cannot leave the effectiveness of the criminal procedure regulation mechanism without any influence [4].

In this case, the effectiveness of the criminal procedure regulation mechanism is achieved by improving the lawmaking and enforcement in criminal proceedings, where normative regulation is designed to ensure stability and necessary similarity in regulation of the criminal procedural relationships, and the enforcement - consideration of a particular conditions, 
the uniqueness of each legal situation [5]. The optimal combination of enforcement and lawmaking, basing on the European Court's case-law, provides versatility over the mechanism of criminal procedure regulation.

The decisions of the European Court as the legal facts are characterized by the following peculiarities: firstly, may contain a legal position, which serve as a rule of behavior for the parties to the criminal proceeding; secondly, influences on specific criminal procedural relationships: causes their occurrence, change or termination; thirdly, as the element of mechanism of criminal proceeding regulations acts as the factor for criminal procedural legislation development, and formation of unified approaches in the enforcement practice; fourthly, changes the enforcement's sense of justice, introduces the case-law principles into the national criminal procedural system [6].

Thus, research of the European Court in determining the criteria for a fair trial demands from Ukraine to create proper conditions for transparency of the judiciary; to improve the efficiency of enforcement of the judgments; to introduce the real competition in the judicial process; to provide a relevant mechanism for avoiding violation of the reasonable time guarantee.

\section{References:}

1. Джеремі Макбрайд Принципи, що визначають тлумачення та застосування Свропейської конвенції з прав людини; за ред. О. Л. Жуковської. Європейська конвенція з прав людини: основні положення, практика застосування, український контекст. К.: ВІПОЛ, 2004. $761 \mathrm{c}$.

2. Джеремі Макбрайд Європейська конвенція 3 прав людини та кримінальний процес. К.: «К.І.С.», 2010. 576 с.

3. Довидас Виткаускас, Григорий Диков. Защита права на справедливое судебное разбирательство в рамках Европейской конвенции о защите прав человека. Серия пособий Совета Европы. Воронеж: ООО Фирма «Элист», 2014211 с.

4. Фулей Т. І. Застосування Європейської конвенції з прав людини при здійсненні правосуддя в Україні : навч.- метод. посіб. для суддів / Акад. суддів України. К. : Гештальт Консалтінг Груп : Прок-Бізнес, 2009. $200 \mathrm{c}$.

5. Шило О. Г. Теоретичні основи та практика реалізації конституційного права людини і громадянина на судовий захист у досудовому провадженні в кримінальному процесі України : дис. ... д-ра юрид. наук : 12.00.09 / Нац. ун-т «Юрид. акад. України ім. Ярослава Мудрого». Харків, 2011. 479 с.

6. Doebbler Curtis F.J. Introduction to International Human Rights Law. CD Publishing; null edition (December 15, 2006). 270 p. 